\title{
Evaluation of Infection Processes and Resulting Disease Caused by Dendryphion penicillatum and Pleospora papaveracea on Papaver somniferum
}

\author{
Bryan A. Bailey, Patricia C. Apel-Birkhold, Nichole R. O'Neill, \\ James Plaskowitz, Sharon Alavi, James C. Jennings, and James D. Anderson
}

First, second, and fifth authors: Biocontrol of Plant Diseases Laboratory; third author: Soybean and Alfalfa Research Laboratory; fourth author: Systematic Botany and Mycology Laboratory; and sixth and seventh authors: Weed Science Laboratory, ARS/USDA, Beltsville, MD 20705. Accepted for publication 22 February 2000.

\begin{abstract}
Bailey, B. A., Apel-Birkhold, P. C., O’Neill, N. R., Plaskowitz, J., Alavi, S., Jennings, J. C., and Anderson, J. A. 2000. Evaluation of infection processes and resulting disease caused by Dendryphion penicillatum and Pleospora papaveracea on Papaver somniferum. Phytopathology 90:699-709.

Two pathogenic fungi of opium poppy, Pleospora papaveracea and Dendryphion penicillatum, were isolated from field material in Beltsville, MD. The processes of infection by these two fungi were studied to determine the optimal environmental conditions for infection. Both fungi formed appressoria capable of penetrating directly through the plant epidermal layer. Of the two fungi, $P$. papaveracea was more aggressive, causing more rapid necrosis. Appressorial formation by $P$. papaveracea occurred as early as $4 \mathrm{~h}$ after application of a conidial suspension to poppy leaves. $P$. papaveracea formed more appressoria than did $D$. penicillatum, especially at cool temperatures $\left(7\right.$ to $\left.13^{\circ} \mathrm{C}\right)$. In greenhouse studies, $P$. papaveracea
\end{abstract}

ABSTRACT

Opium poppy (Papaver somniferum L.) has been grown in many regions of the world $(7,17,31)$. Legal production of opium poppy is defined by international law (17) and is limited to a few countries. The alkaloid morphine, among others, is extracted from the latex of poppy seed capsules for medicinal uses $(7,17)$. Morphine is converted synthetically to the illicit drug heroin $(7,17)$. Considerable resources are used to combat the illegal production and use of heroin in many countries including the United States (20). Although chemical herbicides can be effective in killing opium poppies (14), biologically based herbicides are being considered for use $(1,12,22)$.

Dendryphion penicillatum (Corda) Fr. (synanamorph Helminthosporium papaveris K. Sawada) and Pleospora papaveracea (de Not.) Sacc. (synanamorph Pleospora calvescens (Fr. ex Desmaz.) Tul.) have been reported to be pathogens of opium poppy $(8,18)$ and of the related species Papaver rhoeas (19). Milatovic (19) and Meffert (18) described $P$. papaveracea as an ascomycete overwintering in crop residue and producing perithecia that discharge ascospores in the spring. Both $P$. papaveracea and D. penicillatum pro-

Corresponding author: B. A. Bailey; E-mail address: bbailey@ asrr.arsusda.gov

Mention of trade names or commercial products in this publication is solely for the purpose of providing specific information and does not imply recommendation or endorsement by the U.S. Department of Agriculture.

Publication no. P-2000-0503-01R

This article is in the public domain and not copyrightable. It may be freely reprinted with customary crediting of the source. The American Phytopathological Society, 2000. caused more damage to opium poppy than did $D$. penicillatum when applied in $10 \%$ unrefined corn oil. In the field, $P$. papaveracea was more consistent in its effects on opium poppy from a local seed source designated Indian Grocery. $P$. papaveracea caused higher disease ratings, more stem lesions, and equal or greater yield losses than did D. penicillatum on Indian Grocery. The late-maturing opium poppy variety White Cloud was severely damaged by disease, regardless of formulation or fungal treatment. $P$. papaveracea was the predominant fungus isolated from poppy seed capsules and the only fungus reisolated from the field the following year. These studies provide a better understanding of the infection process and the differences between these two pathogenic fungi and will be beneficial for the development of the fungi as biological control agents.

Additional keywords: conidia, dew period, hyphae, mycoherbicide, pseudothecia, weeds.

duce similarly shaped conidia (18). Characterization of these fungi by morphological and molecular techniques lead us to suggest that the isolates used in these studies are distinct taxa (11). P. papaveracea and $D$. penicillatum have been described as anamorph and teleomorph of one fungus in the literature $(10,27)$, making interpretation of many earlier reports concerning these fungi difficult. These seedborne pathogens $(15,24)$ have a near worldwide distribution, although they are most commonly reported in Europe and Asia (24). Under conditions conducive to disease, their effects can be devastating $(17,24)$.

The infection processes $(9,21)$ of $D$. penicillatum and $P$. papaveracea are not well understood. Because we are interested in determining the potential of using $D$. penicillatum and $P$. papaveracea as bioherbicides, a primary objective was to determine the infection structures and modes of penetration used by $D$. penicillatum and $P$. papaveracea. Additionally, observations were made to determine the environmental optima for infection and disease development by the two fungi and to assess the potential of $P$. papaveracea and $D$. penicillatum to cause disease on opium poppy under field conditions. These observations will be important for distinguishing between the two pathogens and will aid in the development of a mycoherbicide for the control of the illegal cultivation of opium poppy.

\section{MATERIALS AND METHODS}

Fungal culture. D. penicillatum isolate Cf96 and $P$. papaveracea isolate Pf96 were isolated from opium poppies grown in the field in Beltsville, MD, and have been well characterized tax- 
onomically (11). D. penicillatum isolate Cf96 produces abundant microsclerotia, in culture and on necrotic tissue (18), and Dendryphion-type conidiophores (12). The sexual stage has not been observed. While the sexual stage of $P$. papaveracea isolate Pf96 has been observed, Pf96 does not produce Dendryphion-type conidiophores and rarely produces microsclerotia. Both isolates were maintained in the dark at $25^{\circ} \mathrm{C}$ on V8 agar medium ( $100 \mathrm{ml}$ of V8 juice [Campbell Soup Company, Camden, $\mathrm{NJ}$ ], $2 \mathrm{~g}$ of $\mathrm{CaCO}_{3}$, and $15 \mathrm{~g}$ of agar per liter). Unless otherwise indicated, conidia were collected from 6- to 10-day-old V8 agar plates by surface washing with $2 \mathrm{ml}$ of $0.1 \%$ Tween 20 . Conidia were washed twice in deionized water by centrifugation $(5 \mathrm{~min}$ at $10,000 \times g)$ in a $5415 \mathrm{C}$ Eppendorf microfuge (Brinkman Instruments, Inc., Westbury, NY) and resuspended in deionized water plus $0.001 \%$ Tween 20 . Conidia were counted with a hemacytometer and diluted to the required concentrations.

Detached-leaf assays. Detached leaves of opium poppy variety White Cloud (Thompson \& Morgan Ltd., Ipswich, England) were inoculated with 100 conidia per $10 \mu \mathrm{l}$ and placed in petri plates containing sterile moist filter paper to maintain humidity. Using detached leaves maintained a uniform spore density where drops were applied, facilitating sampling. In most cases, the conidia were applied to the adaxial surface of the leaf. For the study of stomatal penetration, the conidia were applied to the abaxial leaf surface. The inoculated leaves were incubated at the temperature ranges of 7 to $13^{\circ} \mathrm{C}, 10$ to $18^{\circ} \mathrm{C}, 16$ to $24^{\circ} \mathrm{C}$, or 21 to $29^{\circ} \mathrm{C}$, with approximately $10 \mathrm{~h}$ of darkness and 14 $\mathrm{h}$ of natural light. The leaves were incubated for $18 \mathrm{~h}$ prior to sectioning, unless otherwise indicated. After incubation, leaf sections containing the conidial suspension were transferred to glass slides, and a drop of lactophenol (20\% phenol, $20 \%$ lactic acid, $40 \%$ glycerol, and $20 \%$ water) containing $0.1 \%$ cotton blue was added to the leaf section (three leaf sections per treatment combination per time point). The percentage of germination and number of appressoria formed were determined by counting germinated conidia and the number of appressoria in five ocular views per leaf section (total of 15 views per treatment combination per time point) using a light microscope (Zeiss Axioskop H/DK Stereo Microscope; Carl Zeiss, Inc., Thornwood, NY). The germ tube length of a minimum of 15 germinated conidia per repetition was measured on a monitor attached to the light microscope and converted to micrometers. A conidium was considered to have germinated if a blue-staining germ tube was visible (minimum length of $0.93 \mu \mathrm{m}$ ). Necrosis measurements were taken daily by examining the infected leaves using a dissecting light microscope (Zeiss Stemi SV11 Stereo Microscope; Carl Zeiss, Inc.) and by estimating the percentage of leaf surface that had become necrotic in the inoculated area. Necrosis was measured for six spots for each treatment combination each day. The conidial production time course (latent period) data were collected by placing a $50-\mu \mathrm{l}$ drop of $0.1 \%$ Tween 20 on the infected spots at 24-h intervals and collecting and counting the conidia with a hemacytometer. Infected spots were sampled only once, and six spots were sampled for each treatment combination each day. All of the experiments were repeated a minimum of three times.

Electron microscopy. Poppy leaves were inoculated with 100 conidia per $10-\mu \mathrm{l}$ drop of $D$. penicillatum or $P$. papaveracea and incubated at $25^{\circ} \mathrm{C}$ for $18 \mathrm{~h}$. Sections of the leaf containing the drop were harvested for electron microscopy examination using standard techniques (16). The leaves were fixed with $3 \%$ glutaraldehyde in $0.05 \mathrm{M}$ sodium phosphate, $\mathrm{pH} 6.8$, overnight at $4^{\circ} \mathrm{C}$. A graded ethanol dehydration was completed prior to critical point drying with $\mathrm{CO}_{2}$ as the transition medium in a Samdri-780-A critical point dryer (Tousimis Research Corp., Rockville, MD). Samples were mounted on aluminum stubs and coated with Au/Pd using a Hummer V Sputter Coater (Technics, Alexandria, VA). The samples were viewed and photographed with a JSM-T300 scanning electron microscope (JEOL, Ltd., Tokyo).
Greenhouse experiments. Viable opium poppy seeds purchased from a local grocery store and designated Indian Grocery were planted in plastic containers $(61 \mathrm{~cm}$ long $\times 41 \mathrm{~cm}$ wide $\times 22 \mathrm{~cm}$ tall) filled to a depth of $15 \mathrm{~cm}$ with Galestown gravelly loamy sand ( $\mathrm{pH} 5.8,77.8 \%$ sand, $12.6 \%$ silt, $9.6 \%$ clay, and $0.6 \%$ organic matter; cation exchange capacity $=4.0$ ). The Weed Science Laboratory is maintaining seed of Indian Grocery for future research uses. Although there is considerable variation among opium poppy cultivars for various botanical and agronomic traits, individual poppy cultivars may be used for culinary and pharmaceutical purposes (25). The containers were divided into four equal plots of 100 seeds each using 9-cm-high plastic edging material. Each plot was considered one replicate, and treatments were replicated four times. Seedlings were grown in a greenhouse cubicle with 14-h days $\left(24^{\circ} \mathrm{C}\right)$ and 10 -h nights $\left(15^{\circ} \mathrm{C}\right)$. Plants were misted intermittently for $2 \mathrm{~h}$ each evening at the start of the dark cycle and for an additional $4 \mathrm{~min}$ each day at midday, resulting in a rate of $0.21 \mathrm{~cm}$ of water per day. The watering regimen was continued throughout the experiment. After 4 weeks, the seedlings were inoculated with $4 \mathrm{ml}$ per replicate of either $0.001 \%$ Tween 20 in water (water) or $0.001 \%$ Tween 20 in $10 \%$ unrefined corn oil (oil) (4) with or without conidia $\left(1 \times 10^{6}\right.$ conidia per $\left.\mathrm{ml}\right)$. The plots were arranged in a twoway factorial completely randomized design with isolate $(P$. papaveracea, D. penicillatum, or control) and formulation $(10 \%$ corn oil or water) as factors. After 15 days, the seedlings were collected from each replicate and rated as not infected, slightly infected $(<50 \%$ stem area necrotic), severely infected $(>50 \%$ stem area necrotic), or dead. The total number of seedlings within each replicate with each rating was summed and expressed as a percentage of the total number of seedlings per replicate. The experiment was repeated.

Field experiments. Duplicate field experiments were initiated 4 weeks apart at Beltsville, MD. Seeds of Indian Grocery and the opium poppy variety White Cloud were planted in square $10.2-\mathrm{cm}$ pots on Julian dates 76 and 106 (17 March and 16 April) of 1997 and incubated in a controlled temperature $\left(21^{\circ} \mathrm{C}\right.$ light and $17^{\circ} \mathrm{C}$ dark) and light cycle (12 h of light and $12 \mathrm{~h}$ of darkness) growth chamber. Six weeks after planting, the opium poppy plants were transplanted to field plots $\left(38 \mathrm{~cm} \times 38 \mathrm{~cm}, 0.145 \mathrm{~m}^{2}\right)$ containing four plants arranged in a square with plants $19 \mathrm{~cm}$ apart and $19 \mathrm{~cm}$ between plots. Each plot was considered a replicate, and treatments were replicated five times. Two weeks after transplanting, plants were treated with $3 \mathrm{ml}$ per plant of either $0.001 \%$ Tween 20 in water (water) or $0.001 \%$ Tween 20 in $10 \%$ unrefined corn oil (oil) with or without conidia $\left(2 \times 10^{5}\right.$ conidia per ml). Plots were arranged in a three-way factorial completely randomized design with opium poppy type (White Cloud or Indian Grocery), isolate (P. papaveracea, D. penicillatum, or control) and formulation (oil or water) as factors. Disease severity was recorded weekly starting on Julian date 157 (7 June) and continuing until the poppy plants senesced. A rating scale of 0 to $100 \%$ necrotic tissue was used, and separate ratings were made for the lower and upper halves of each plant. Stems of each plant were observed weekly for the presence or absence of lesions greater than $2.54 \mathrm{~cm}$ in length. At the end of the season, the capsules were harvested and weighed.

Harvested capsules were crushed, passed through a 1-mm sieve, and milled using a 40-mesh screen. This tissue was plated on moist Whatman No. 1 filter paper (Whatman International Ltd., Maidstone, England) in petri dishes to allow for identification of the fungi present in plots at the season's end. The fungi growing out of the tissue were identified based on the size of conidia and the presence or absence of microsclerotia. $D$. penicillatum produces smaller conidia than does $P$. papaveracea and abundant microsclerotia. The data were recorded as a percentage of plots infested with $P$. papaveracea, D. penicillatum, or both and as a percentage of total fungal growth from the infested material on each plate represented by these fungi. Tissues were sampled from three plots for each treatment combination for each field experiment. 


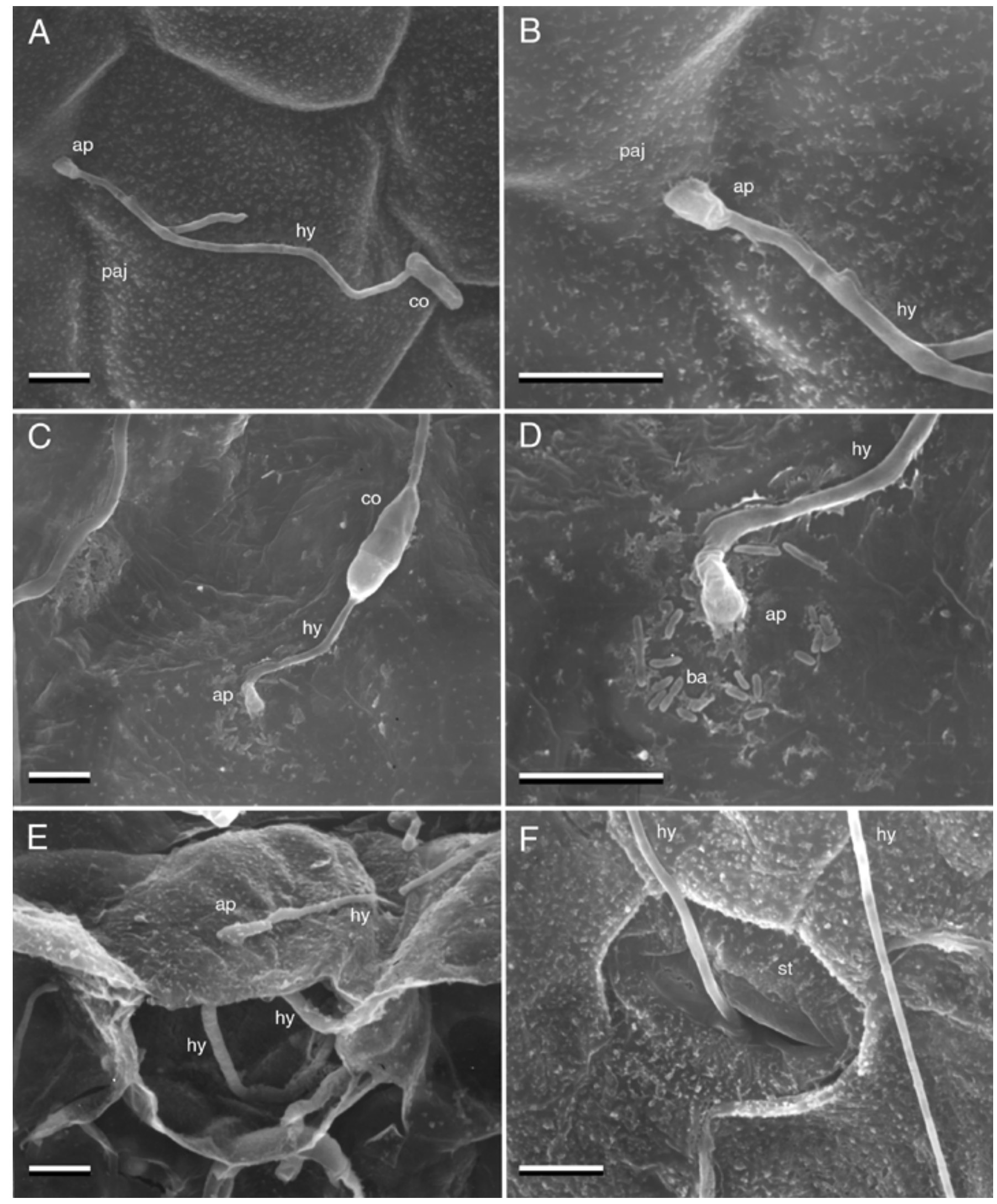

Fig. 1. Scanning electron micrographs illustrating infection of Pleospora papaveracea and Dendryphion penicillatum on Papaver somniferum. Bar $=10 \mu \mathrm{m}$. A, D. penicillatum conidium (co) that germinated and formed a branched hypha (hy) and appressorium (ap). B, An increased magnification of the appressorium in A that has formed at the periclinal and anticlinal cell wall junction (paj). C, A P. papaveracea conidium that has hyphae that originated from both polar cells and formed an appressorium in the middle of the outer periclinal cell wall. D, An increased magnification of the appressorium in $\mathbf{C}$ that shows bacteria (ba) surrounding the penetration site of the fungus. E, Freeze-fractured Papaver somniferum leaf material infected with $P$. papaveracea. The appressorium can be seen on the outer periclinal cell wall with the invading hypha within the plant cells. F, A P. papaveracea hypha that has penetrated the abaxial surface of the poppy leaf via a stomate (st). 
After the capsules were harvested, the poppy plant residue that was infested with $P$. papaveracea and $D$. penicillatum was chopped and left on the soil surface of the test plots. These plots were kept fallow through the winter, and opium poppies were planted into the stubble on Julian dates 90 and 118 (31 March and 28 April) the following spring 1998. Lesions that developed on the poppy leaves were surface-disinfested for $2 \mathrm{~min}$ in $0.525 \%$ sodium hypochlorite, rinsed twice in sterile deionized water, and plated on moist Whatman No. 1 filter paper in petri dishes. The isolates growing out of the tissue were identified as $P$. papaveracea or D. penicillatum based on the size of conidia and the presence or absence of microsclerotia.

Data analysis. All data were analyzed using the SAS general linear models procedure (version 6.04; SAS Institute Inc., Cary, NC). Data in which time was not a factor were analyzed using analysis of variance (ANOVA). Mean comparisons were carried out using least significant difference $(P \leq 0.05)$ when appropriate. Data with time as a factor were analyzed using the repeated measures ANOVA. After repeated measures analysis of field data, degrees of freedom for the isolate, or isolate over time sums of squares, were separated into planned contrasts comparing the fungal-treated plots with the control plots.

Temperature was always a significant factor in the detached-leaf studies. Therefore, the statistical analysis for the detached-leaf studies was carried out for each temperature regimen separately, unless otherwise indicated. Because disease development is influenced by plant growth stage and because Indian Grocery finished flowering 2 to 3 weeks before White Cloud, data for Indian Grocery and White Cloud were separated prior to statistical analysis. In addition, there was only a single date with significant disease ratings for the upper half of White Cloud plants. As a result, the disease ratings of the upper half of White Cloud plants were analyzed by ANOVA separately.

\section{RESULTS}

Scanning electron microscopy. Scanning electron microscopy was used to examine the two fungi for possible differences in the infection process (Fig. 1). Both fungi penetrated the surface via appressoria and penetration pegs. Scanning electron microscopy also revealed that plant cells were penetrated most frequently via appressoria produced at the periclinal and anticlinal cell wall junctions (Fig. 1A and B) $(78 \pm 4 \%$ for D. penicillatum and $63 \pm 5 \%$ for $P$. papaveracea) compared with the middle of periclinal cell walls (Fig. 1C and E). When the abaxial surface of the leaf was inoc- ulated, occasional stomatal penetration (Fig. 1F) occurred $(13.3 \pm$ $0.8 \%$ for $D$. penicillatum and $6.6 \pm 3.5 \%$ for $P$. papaveracea).

Detached-leaf assays. The mean conidial lengths of $P$. papaverace $a$ and $D$. penicillatum from plate cultures were 23.1 and $16.0 \mu \mathrm{m}$, respectively. Conidia taken from plate cultures were smaller than the conidia produced on diseased tissue (20.3 to $75.5 \mu \mathrm{m} \times 5.3$ to $8.6 \mu \mathrm{m}$ for P. papaveracea, and 14.5 to $33.7 \mu \mathrm{m} \times 3.7$ to $7.9 \mu \mathrm{m}$ for $D$. penicillatum) (11). Both fungi produced approximately the same number of germ tubes per conidium, primarily from the polar cells ( $98 \pm 1 \%$ for $D$. penicillatum and $96 \pm 2 \%$ for $P$. papaveracea).

By examining germination, germ tube growth, and appressorial formation of $D$. penicillatum and $P$. papaveracea at different temperatures, it was determined that the conidial germination, germ tube growth, and appressorial formation differed for isolate and temperature (Table 1). Conidial germination was consistent, though slightly reduced, at the lower temperatures (Fig. 2A). As the temperature was decreased, germ tube lengths decreased (Fig. 2B). This study indicated that $P$. papaveracea has more germ tube growth than does $D$. penicillatum at all temperatures, including 7 to $13^{\circ} \mathrm{C}$. At all temperature ranges, $P$. papaveracea produced more appressoria per conidium than did $D$. penicillatum $18 \mathrm{~h}$ after inoculation (Fig. 2C).

High $\left(21\right.$ to $29^{\circ} \mathrm{C}$ ) and low $\left(7\right.$ to $13^{\circ} \mathrm{C}$ ) incubation temperature ranges were used to assess conidial viability, vigor, and infection on poppy leaves as affected by prolonged incubation at $25^{\circ} \mathrm{C}$ in plate culture on V8 medium (Table 1). These experiments were carried out to examine culture age, because production of conidia in liquid culture is limited and solid culture may be the only source of conidial inoculum. The optimum incubation time for conidial germination, maximum germ tube growth, and appressorial formation was 6 to 8 days (data not shown). Both fungi showed a decrease in the percentage of germination, maximum germ tube growth, and appressorial formation when held on $\mathrm{V} 8$ medium at $25^{\circ} \mathrm{C}$ for 24 days or longer, as well as an increase in the aging effect at the cool temperature range (data not shown). Formation of appressoria by either fungus decreased more than $50 \%$ at both temperature ranges when conidia were maintained for at least 24 days at $25^{\circ} \mathrm{C}$ (data not shown). The decrease in the percentage of conidia that gave rise to appressoria as the conidia aged was dependent upon the frequency of conidial germination and germ tube growth.

The germination of conidia and the formation of appressoria of $D$. penicillatum and $P$. papaveracea were further examined by a time course study (Table 1). At 21 to $29^{\circ} \mathrm{C}$, both fungi had germinated nearly $100 \%$ by $4 \mathrm{~h}$ (Fig. $3 \mathrm{~A}$ ), whereas germination at 7 to $13^{\circ} \mathrm{C}$ was only slightly delayed (Fig. 3B). Very little growth of the

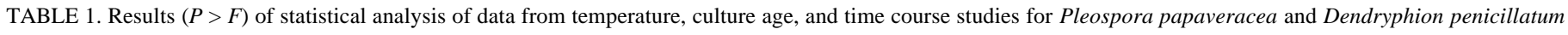
infection of detached opium poppy leaves

\begin{tabular}{|c|c|c|c|c|c|c|c|c|c|c|c|c|c|c|c|c|c|c|}
\hline \multirow[b]{3}{*}{ Factors } & \multicolumn{3}{|c|}{ Temperature $(\mathrm{T})^{\mathrm{u}}$} & \multicolumn{6}{|c|}{ Culture age $(\mathrm{CA})^{\mathrm{v}}$} & \multicolumn{8}{|c|}{ Time course of infection ${ }^{w}$} & \multirow{3}{*}{$\begin{array}{l}\text { Spore } \\
\text { prod. }\end{array}$} \\
\hline & \multirow{2}{*}{$\begin{array}{l}\text { Germi- } \\
\text { nation }^{\mathrm{x}}\end{array}$} & \multirow{2}{*}{$\begin{array}{c}\text { Appres- } \\
\text { soria }\end{array}$} & \multirow{2}{*}{$\begin{array}{l}\text { Germ } \\
\text { tube }\end{array}$} & \multicolumn{2}{|c|}{ Germination } & \multicolumn{2}{|c|}{ Appressoria } & \multicolumn{2}{|c|}{ Germ tube } & \multicolumn{2}{|c|}{ Germination } & \multicolumn{2}{|c|}{ Appressoria } & \multicolumn{2}{|c|}{ Germ tube } & \multicolumn{2}{|c|}{ Necrosis } & \\
\hline & & & & $\operatorname{High}^{\mathrm{y}}$ & Low $^{\mathrm{y}}$ & High & Low & High & Low & High & Low & High & Low & High & Low & High & Low & \\
\hline Isolate (I) & $0.001 * * * \mathrm{Z}$ & $0.009^{* *}$ & $0.001 * * *$ & $0.001^{* * *}$ & $0.001^{* * * *}$ & $0.001^{* * *}$ & 0.918 & $0.004^{* *}$ & 0.087 & & & & & & & & & \\
\hline $\mathrm{T}$ & $0.001 * * *$ & $0.011^{*}$ & $0.004 * *$ & & & & & & & & & & & & & & & \\
\hline $\mathrm{I} \times \mathrm{T}$ & 0.135 & 0.271 & 0.224 & & & & & & & & & & & & & & & \\
\hline $\mathrm{CA}$ & & & & $0.001^{* * *}$ & $0.001^{* * * *}$ & $0.001^{* * *}$ & $0.001 * * *$ & $0.001 * * *$ & $0.002 * *$ & & & & & & & & & \\
\hline $\mathrm{I} \times \mathrm{CA}$ & & & & 0.180 & 0.063 & $0.001^{* * *}$ & $0.001 * * *$ & 0.099 & 0.260 & & & & & & & & & \\
\hline Isolate & & & & & & & & & & 0.345 & 0.468 & 0.001 **** & $0.001 * * *$ & 0.415 & 0.614 & $0.001 * * *$ & $0.001 * * * *$ & 0.001 **** \\
\hline Hours $(\mathrm{H})$ & & & & & & & & & & $0.031^{*}$ & $0.001 * * *$ & $0.001 * * *$ & $0.001 * * *$ & 0.001 *** & $0.001^{* * *}$ & $0.001 * * *$ & $0.001 * * *$ & 0.001 *** \\
\hline $\mathrm{I} \times \mathrm{H}$ & & & & & & & & & & 0.074 & 0.448 & 0.103 & $0.001 * * *$ & 0.256 & 0.108 & $0.001^{* * * *}$ & $0.001^{* * * *}$ & 0.651 \\
\hline
\end{tabular}

${ }^{\mathrm{u}}$ Results of statistical analysis of data from two temperature experiments with detached leaves. The data were combined before analysis and are presented in Figure 2.

${ }^{v}$ Results of statistical analysis of data from two culture age experiments with detached leaves.

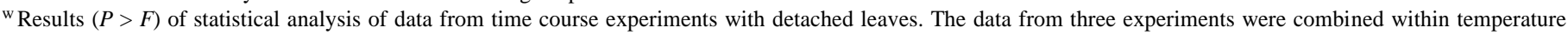
regimens before analysis for germination, appressorial production, and germ tube length and are presented in Figure 3. Data from an individual experiment within temperature regimens are presented in Figure 4 for necrosis and spore production (spore prod.).

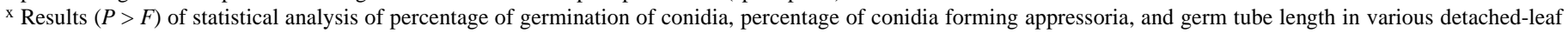
experiments.

${ }^{\text {y }}$ Results $(P>F)$ of statistical analysis of data from various detached-leaf experiments carried out at high $\left(21\right.$ to $\left.29^{\circ} \mathrm{C}\right)$ and low $\left(7\right.$ to $\left.13^{\circ} \mathrm{C}\right)$ temperatures.

$\mathrm{z} *$, **, and *** indicate that the factors were significant at the $P \leq 0.05,0.01$, and 0.001 levels, respectively. 
germ tubes had occurred by $4 \mathrm{~h}$ (Figs. 3B and 4C). By 8 h, P. papaveracea and $D$. penicillatum grew rapidly at 21 to $29^{\circ} \mathrm{C}$ (Fig. $3 \mathrm{C})$. By $22 \mathrm{~h}$, the germ tubes developed at the warmer temperature were too long to be measured effectively (Fig. 3C). The amount of growth, as determined by germ tube length when incubated at the cooler temperature range, was reduced by more than half of the warmer temperature germ tube growth after $8 \mathrm{~h}$ (Fig. 3D). The rate of appressorial formation was greater for $P$. papaveracea than for $D$. penicillatum $4 \mathrm{~h}$ after inoculation at 21 to $29^{\circ} \mathrm{C}$ (Fig. 3E). Formation of appressoria was delayed at 7 to $13^{\circ} \mathrm{C}$ for both fungi, but $P$. papaveracea had a faster rate of appressorial formation (Fig. 3F).

Necrosis measurements were taken for 7 days after inoculation of the fungal pathogens onto the poppy leaves. The development of necrosis was influenced by the interaction of isolate and time. $P$. papaveracea caused $87 \%$ necrosis within $24 \mathrm{~h}$ after treatment at the 21 to $29^{\circ} \mathrm{C}$ temperature range, whereas D. penicillatum took

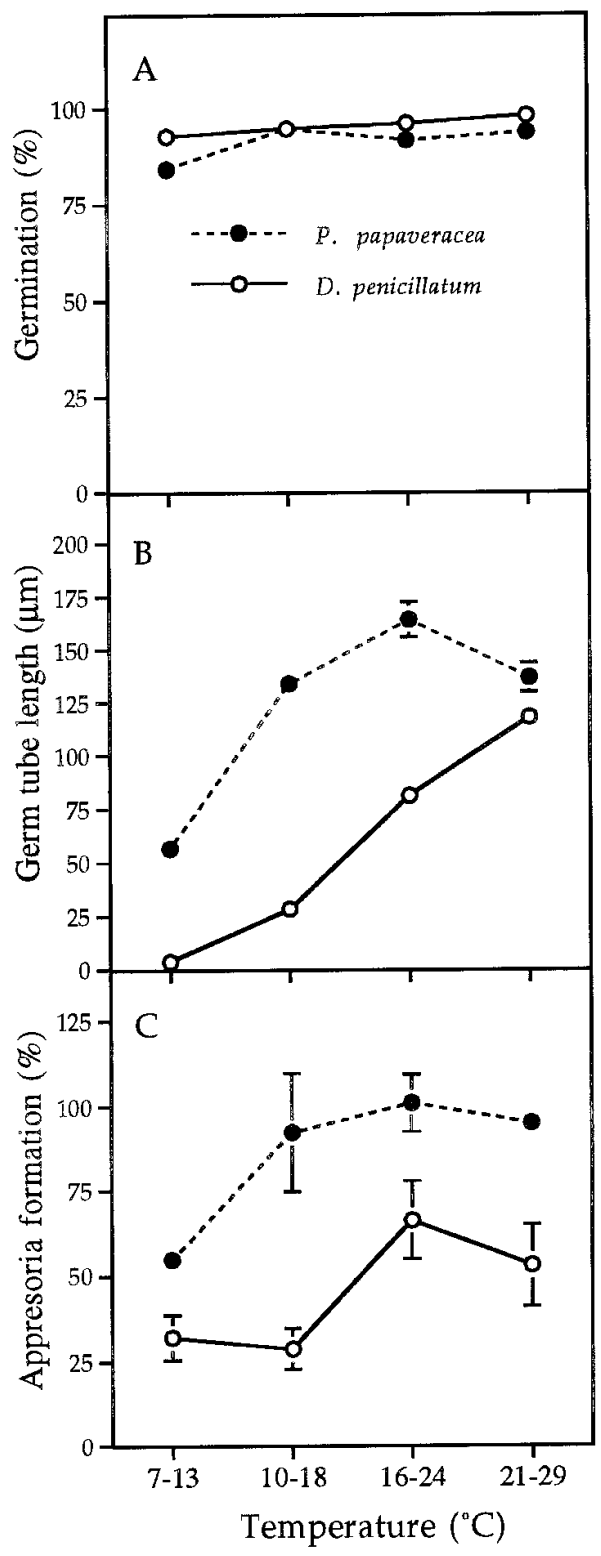

Fig. 2. Fungal responses to temperature. A, Percentage of germination; B, germ tube length; and $\mathbf{C}$, appressorial formation of Pleospora papaveracea and Dendryphion penicillatum on Papaver somniferum, measured at four different temperature ranges. The data from two temperature experiments were combined before analysis (Table 1) and are presented here. Standard error bars are provided for each data point. If error bars are not seen, they are smaller than the symbol. more than 72 h to reach $100 \%$ necrosis (Fig. 4A). Necrosis was delayed for both fungi at 7 to $13^{\circ} \mathrm{C}$, and after 7 days, $D$. penicillatum had caused only $4 \%$ necrosis. $P$. papaveracea began causing necrosis by $72 \mathrm{~h}$ at 7 to $13^{\circ} \mathrm{C}$ (Fig. 4B).

Both $P$. papaveracea and $D$. penicillatum generated similar conidial production curves (Fig. 4C). However, the production of conidia by $D$. penicillatum was significantly less (Table 1 ) compared with that of $P$. papaveracea at 21 to $29^{\circ} \mathrm{C}$ (Fig. 4). At the cooler temperature, neither $D$. penicillatum nor $P$. papaveracea produced a significant amount of conidia (data not shown).

Greenhouse studies. In greenhouse studies, the use of $10 \%$ corn oil in the formulation resulted in $100 \%$ infection of opium poppy by $P$. papaveracea and nearly $100 \%$ infection by $D$. penicillatum (Fig. 5). As much as $16.5 \%$ of the poppies remained asymptomatic when treated with the water plus $0.001 \%$ Tween 20 formulation of either pathogen. The corn oil formulation also significantly $(P \leq$ $0.05)$ increased the number of poppies showing severe basal necrosis ( $>50 \%$ necrotic) or the number that died due to treatment compared with the corresponding numbers due to water treatment. $P$. papaveracea in $10 \%$ corn oil killed more seedlings $(57.7 \%)$ than did D. penicillatum in $10 \%$ corn oil $(34.7 \%)$ or any of the water plus $0.001 \%$ Tween 20 formulations $(\leq 1.5 \%)$. Similar results were obtained when the experiment was repeated.

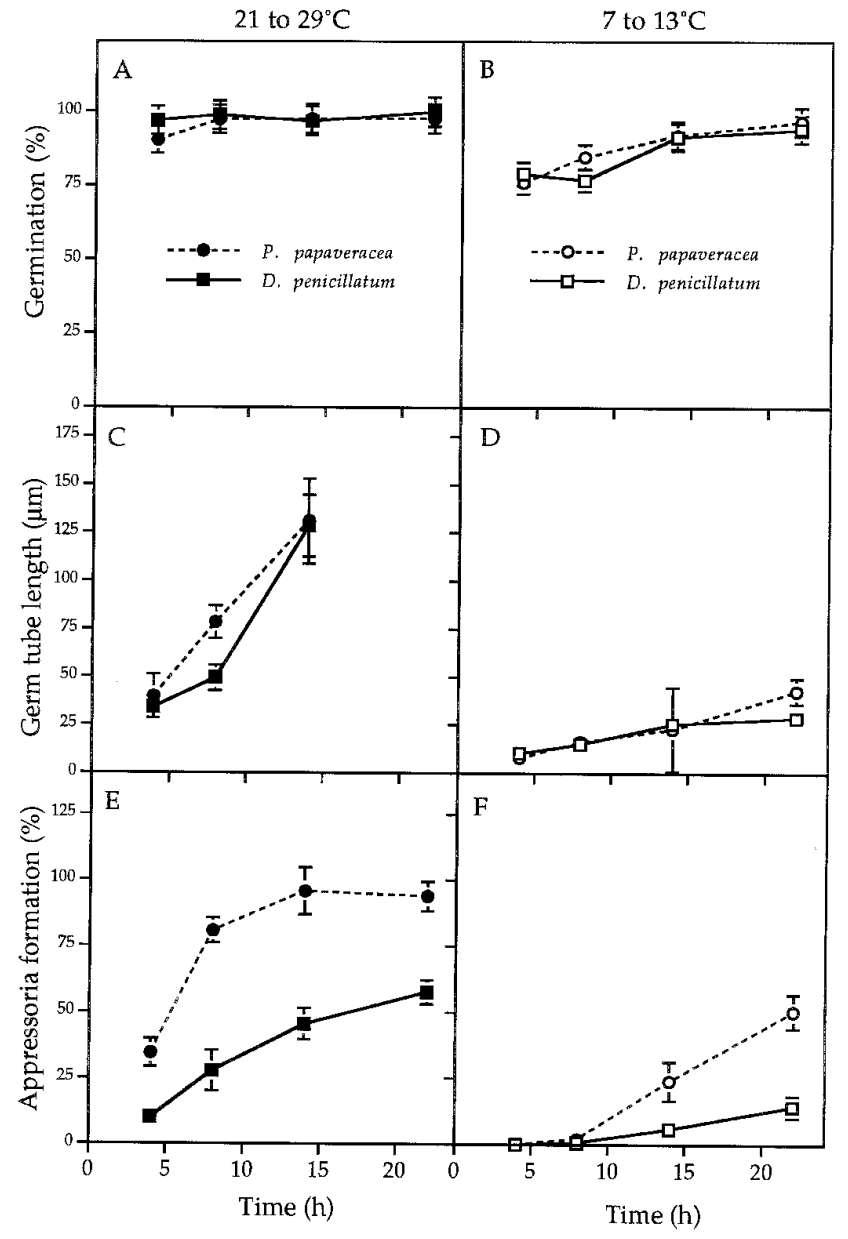

Fig. 3. Time course of growth and infection. A and B, Percentage of germination; $\mathbf{C}$ and $\mathbf{D}$, germ tube length; and $\mathbf{E}$ and $\mathbf{F}$, appressorial formation from germinating conidia of Pleospora papaveracea and Dendryphion penicillatum on Papaver somniferum measured for infections in the two temperature ranges at $4,8,14$, and $22 \mathrm{~h}$ after inoculation onto poppy leaves. The data from three time course experiments were combined within temperature regimens before analysis (Table 1). Standard error bars are provided for each data point. If error bars are not seen, they are smaller than the symbol. 
Field experiments. The 1997 growing season remained cool through May. There was limited rainfall throughout the growing season. Although planted and inoculated a month apart, the two Indian Grocery plantings finished flowering within 1 week of each other. The two White Cloud plantings finished flowering on essentially the same date, about 2 to 3 weeks later than Indian Grocery.

In both field experiments, the weeks $\times$ isolate interaction was significant for necrosis of both the upper and lower halves of Indian Grocery (Tables 2 and 3). Formulation also was significant for bottom necrosis in field experiment II (Table 3). In field experiment $\mathrm{I}$, the disease ratings were highest in the $P$. papaveraceatreated plots of Indian Grocery, regardless of formulation (Fig. 6). The disease rating for the lower half of the plant was highest for the $P$. papaveracea plus oil treatment for the first two ratings periods, but this effect was less pronounced as the season progressed. In field experiment II, the Indian Grocery plants treated with $P$. papaveracea plus oil or $D$. penicillatum plus oil had higher disease ratings than their respective treatments with fungi plus water (Fig. 7). When applied in the same formulation, both fungi had very similar disease ratings for the upper half of the plant. Disease ratings for control plots were uniform, regardless of formulation, and progressed at a significantly slower rate (Figs. 6 and 7) than that of plots treated with $P$. papaveracea $(P \leq 0.004)$ or $D$. penicillatum $(P \leq 0.029)$. The exception was the upper half of plants treated with $D$. penicillatum in field experiment I $(P=0.940)$. By the end of the season, the disease ratings for control plots approached the same levels as observed in the fungal-treated plots due to the spread of the pathogens from neighboring inoculated plots and background pathogen populations.

Although isolate was a significant factor either over time (Table 2, field experiment I) or alone (Table 3, field experiment II) for disease rating of White Cloud, the effects of isolates on White Cloud were minor compared with their effects on Indian Grocery (Figs. 7 and 8). For White Cloud, the disease rating did not increase until late in the season and then rapidly increased once the plants began to flower. Disease on White Cloud progressed from very low disease ratings to greater than $50 \%$ necrosis on the bot-

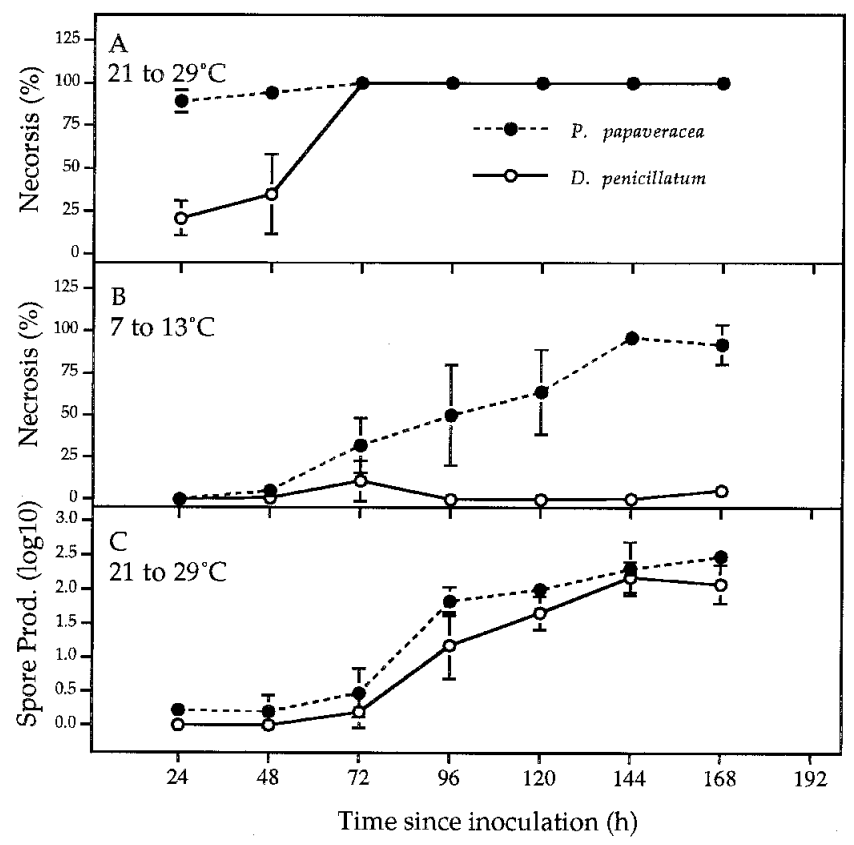

Fig. 4. Time course of appearance of necrosis and secondary conidia production following initial infection. A and B, Necrosis of the inoculated area; and $\mathbf{C}$, conidia production was measured at the two temperature ranges over time. The data from two time course experiments were analyzed separately within temperature regimens (Table 1), and results of a single experiment are presented. Standard error bars are provided for each data point. If error bars are not seen, they are smaller than the symbol. tom half of plants in 1 week. The following week, all the plants were $100 \%$ necrotic (data not shown).

The development of stem lesions was strongly influenced by isolate and formulation (Tables 2 and 3). In field experiment I, only $P$. papaveracea caused a significant number of stem lesions, with the greatest number being produced by $P$. papaveracea in water (Table 4). In field experiment II, both $P$. papaveracea and $D$. penicillatum caused a significant number of stem lesions compared with the number in the controls, and conidia in water once again significantly increased stem lesion development compared with conidia in $10 \%$ corn oil (Table 4). Stem lesions were not observed on White Cloud until late in the season (data not shown).

Capsule production by Indian Grocery was significantly affected by isolate in both field experiments (Tables 2 and 3). In field experiment I, $P$. papaveracea reduced capsule weight by $28 \%$ compared with that of the control (Table 5). Plots treated with $P$. papaveracea in water had the lowest capsule weight due to lodging before capsule development. In field experiment II, both $P$. papaveracea and $D$. penicillatum reduced capsule weight from Indian Grocery an average of $20 \%$ compared with that of the control (Table 5). Formulation did not have a significant effect on yield in either experiment (Tables 2 and 3). Although the P. papaveracea treatment was associated with reduced capsule weight of White Cloud in field experiment II (Table 5), White Cloud, in general, had extremely low capsule weight, with many capsules failing to develop from diseased flowers in both experiments.

The majority of plots evaluated had capsules infested by $P . p a-$ paveracea, regardless of the treatment applied (Fig. 8A). P. papaveracea was the most frequently isolated fungus from infected capsules (Fig. 8B). Most capsules from control plots were infected by one or both fungi. The results were similar for both field experiments.

Over the winter, black perithecia that were visible without magnification formed in the poppy stubble. Starting in mid-April, 2 weeks after transplanting poppies into the field, distinct dark brown lesions were observed on poppy leaves. Of the 170 lesions sampled, all were found to be infected by $P$. papaveracea based on the size of conidia and absence of microsclerotia. Microsclerotial-producing isolates similar to $D$. penicillatum were not observed growing from any of the lesions.

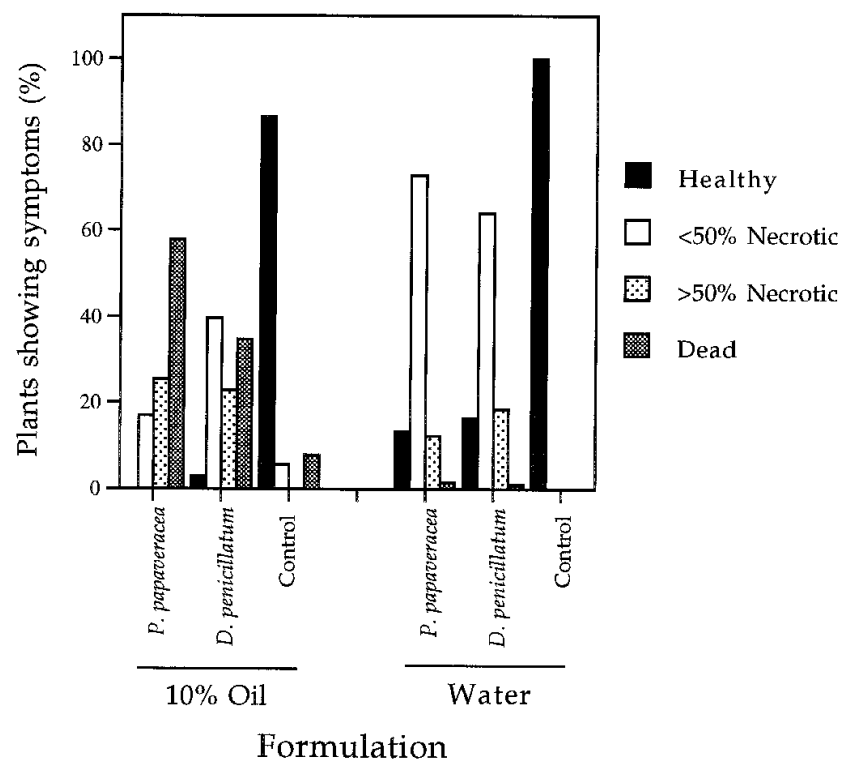

Fig. 5. Development of disease in 4-week-old greenhouse-grown opium poppy Indian Grocery seedlings 15 days after inoculation with conidia $\left(1 \times 10^{6}\right.$ conidia per $\mathrm{ml}$ ) of Dendryphion penicillatum and Pleospora papaveracea in $0.001 \%$ Tween 20 in water (water) or $0.001 \%$ Tween 20 in $10 \%$ unrefined corn oil (10\% oil). The data are presented as a percentage of treated plants showing the indicated symptom levels for each treatment combination. 


\section{DISCUSSION}

Throughout these experiments, differences in growth of the two fungal pathogens were apparent. P. papaveracea isolate Pf96 consistently produced more appressoria (Fig. 2) and caused more rapid necrosis (Fig. 4) than did D. penicillatum isolate Cf96 at the temperature ranges studied (Figs. 2 and 3 ). Whereas the percentage of germination of the conidia from 6- to 8-day-old plates at the two temperatures was similar, the overall germ tube length was dramatically decreased in both fungi at the cooler temperature range of 7 to $13^{\circ} \mathrm{C}$ (Fig. 2). The optimal viability of conidia was obtained from 6- to 8-day-old plates (data not shown). Although it has been recognized that $D$. penicillatum and $P$. papaveracea produce appressoria during infection (18), the importance of appressoria in the infection process and the conditions under which appressoria are produced by these fungi has not previously been detailed in the literature. The increased number of appressoria produced by $P$. papaveracea may increase its ability to survive on the plant surface prior to penetration by functioning as a survival structure, as is the case with the mycoherbicide Colletotrichum gloeosporioides f. sp. malvae (13). P. papaveracea isolate Pf96 produces more secondary conidia in defined infection sites than does $D$. penicillatum isolate Cf96 following infection (Fig. 4). The increased secondary conidia production by $P$. papaveracea isolate Pf96 would be expected to increase the fungal inoculum over the field season (30). Poppy is normally grown at high elevation, because cooler temperatures increase opium yield $(17,26)$. In addition to conidial formation, it is important that the fungal biological control agent be able to germinate and infect quickly when applied in the field (4). P. papaveracea isolate Pf96 formed appressoria at a faster rate than did $D$. penicillatum isolate Cf96 under the conditions evaluated. $P$. papaveracea isolate Pf96 required 8 to $14 \mathrm{~h}$ of moisture for maximal appressorial formation at 21 to $29^{\circ} \mathrm{C}$, while $D$. penicil- latum isolate Cf96 required 14 to $22 \mathrm{~h}$ of moisture at the same temperature (Fig. 3).

Our field treatments were applied under very cool conditions in early to mid-spring. The rate of disease development in these field experiments increased as the season progressed. Warm temperatures and high moisture $(2,3)$ favor the diseases caused by $P$. papaveracea and $D$. penicillatum. Environmental constraints such as temperature and dew period are major limiting factors in the efficacy of bioherbicides $(4,28,29)$. As expected based on the detachedleaf experiments, $P$. papaveracea isolate Pf96 was more aggressive at causing foliar symptoms than was $D$. penicillatum isolate Cf96 in both field and greenhouse experiments.

At the end of the growing season in the field, $P$. papaveracea was the predominant fungus ( $>97.9 \%$ for Indian Grocery) observed on capsules from the plots it was applied to and in the majority of control plots. $P$. papaveracea was also isolated at equal frequency to $D$. penicillatum from capsules in plots originally treated with $D$. penicillatum. The high frequency of isolation of both fungi from capsules is consistent with observations that the pathogens are transmitted by infected seed $(15,24)$.

When poppies were planted into poppy stubble infected with both $P$. papaveracea isolate Pf96 and D. penicillatum isolate Cf96, only $P$. papaveracea was recovered, possibly due to its ability to produce ascospores in the spring. The lower temperature optimum of $P$. papaveracea isolate Pf96 may be necessary for infection by ascospores under natural conditions in the spring (19). The sexual stage of $D$. penicillatum was not observed $(8,18)$.

The rate of disease development was highly dependent on the plant's growth stage. The plants were still in the rosette stage and had not initiated flowering when the formulations were applied. White Cloud did not become severely infected until flower and capsule development had begun, despite a high background level of inoculum provided from the earlier maturing Indian Grocery plants

TABLE 2. Results $(P>F)$ of statistical analysis of field experiment I in 1997 testing the effects of Pleospora papaveracea and Dendryphion penicillatum as bioherbicides of opium poppy

\begin{tabular}{|c|c|c|c|c|c|c|c|}
\hline \multirow[b]{2}{*}{ Source } & \multicolumn{4}{|c|}{ Indian Grocery } & \multicolumn{3}{|c|}{ White Cloud } \\
\hline & Lower $^{\mathrm{w}}$ & Upper $^{\mathrm{w}}$ & Yield $^{x}$ & Stem lesion & Lower & Upper $(73 \text { days })^{y}$ & Yield \\
\hline Formulation & 0.240 & 0.913 & 0.378 & $0.039 *$ & 0.625 & 0.261 & 0.678 \\
\hline Isolate & $<0.001 * * * \mathrm{z}$ & 0.055 & $0.020^{*}$ & $0.004 * *$ & $0.005^{* *}$ & 0.136 & 0.379 \\
\hline Weeks & $<0.001 * * *$ & $<0.001 * * *$ & & & $<0.001 * * *$ & & \\
\hline Weeks $\times$ formulation & 0.086 & 0.147 & & & 0.990 & & \\
\hline Weeks $\times$ isolate & $<0.001 * * *$ & $0.010^{* *}$ & & & $0.031^{*}$ & & \\
\hline
\end{tabular}

w Percentage of necrotic tissue was estimated for the upper and lower halves of the plant.

$x$ Yield equals the weight of capsules per plant.

y There was only a single date 73 days after treatment with significant disease ratings for the upper half of White Cloud plants, and the data were analyzed by analysis of variance alone.

$\mathrm{z} * * *$, and $* * *$ indicate that the factors were significant at the $P \leq 0.05,0.01$, and 0.001 levels, respectively.

TABLE 3. Results $(P>F)$ of statistical analysis of field experiment II in 1997 testing the effects of Pleospora papaveracea and Dendryphion penicillatum as bioherbicides of opium poppy

\begin{tabular}{|c|c|c|c|c|c|c|c|}
\hline \multirow[b]{2}{*}{ Source } & \multicolumn{4}{|c|}{ Indian Grocery } & \multicolumn{3}{|c|}{ White Cloud } \\
\hline & Lowerw & Upperw $^{w}$ & Yield $^{x}$ & Stem lesion & Lower & 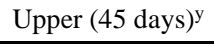 & Yield \\
\hline Formulation & $0.013^{* \mathrm{z}}$ & 0.141 & 0.150 & $<0.001 * * *$ & 0.054 & 0.975 & 0.681 \\
\hline Isolate & $<0.001 * * *$ & $<0.001 * * *$ & $0.002 * *$ & $<0.001 * * *$ & $<0.001 * * *$ & 0.103 & $0.035^{*}$ \\
\hline Weeks & $<0.001 * * *$ & $<0.001 * * *$ & & & $<0.001 * * *$ & & \\
\hline Weeks $\times$ formulation & 0.118 & 0.154 & & & 0.680 & & \\
\hline Weeks $\times$ isolate & $<0.001 * * *$ & $<0.001 * * *$ & & & 0.971 & & \\
\hline
\end{tabular}

${ }^{w}$ Percentage of necrotic tissue was estimated for the upper and lower halves of the plant.

$\mathrm{x}$ Yield equals the weight of capsules per plant.

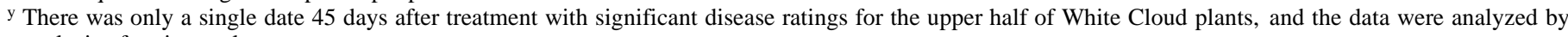
analysis of variance alone.

$\mathrm{z} * * *$, and $* * *$ indicate that the factors were significant at the $P \leq 0.05,0.01$, and 0.001 levels, respectively. 
in the same area. Later maturing varieties have been reported to suffer more from the disease (2). When White Cloud began to mature (capsule development), the rate of disease development increased greatly, resulting in almost total yield loss, demonstrating the explosive nature of this disease.

The pathogens were more effective at killing young opium poppies in the greenhouse than larger plants in the field. This could be attributed to the more conducive conditions for disease in the green- house, the fivefold-higher spore concentrations used in the greenhouse, and the influence of direct sunlight on plant growth and development in the field, either alone or in combination. For example, it was observed that opium poppy plants develop a much more waxy leaf surface when transferred to the field. For other mycoherbicides, spore concentrations of $1.8 \times 10^{7} / \mathrm{m}^{2}$ (COLLEGO: $C$. gloeosporioides f. sp. aeschynomene) and $6.0 \times 10^{7} / \mathrm{m}^{2}$ (BIOMAL: C. gloeosporioides f. sp. malvae) have been used in commercial
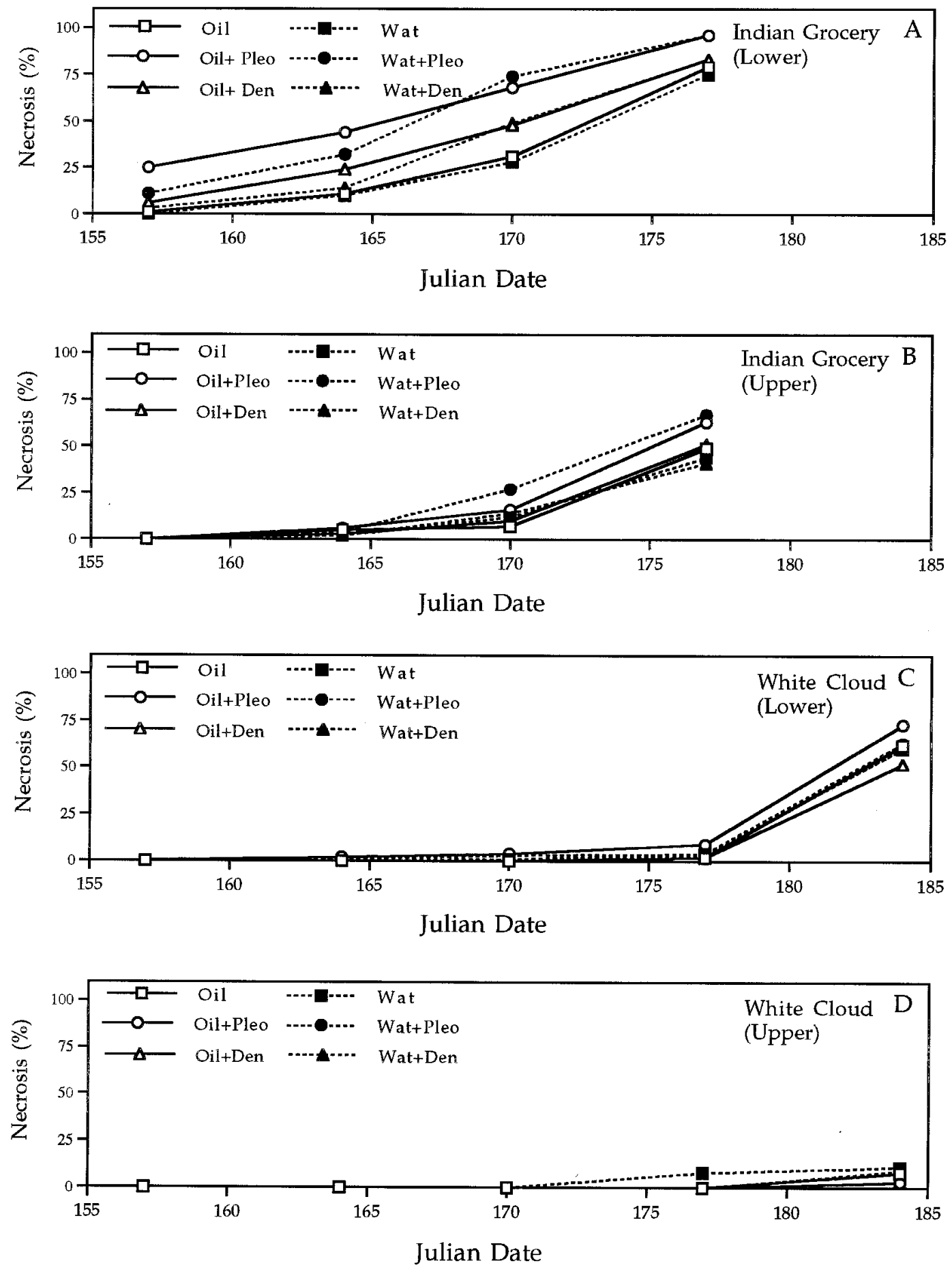

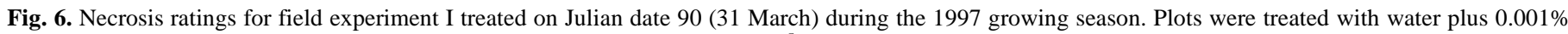

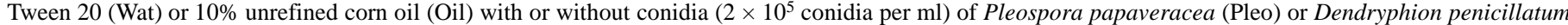

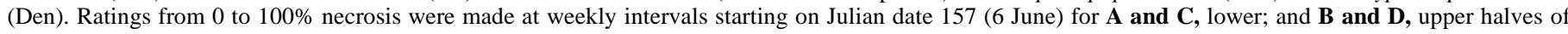
individual plants within four-plant plots. The data presented are the means for five plots. The statistical analysis is presented in Table 2. Contrast comparisons $(P>F)$ between the necrosis ratings of plots treated with P. papaveracea and control plots were $<0.001$ and 0.004 for Indian Grocery and 0.264 and 0.048 for White Cloud for the lower and upper halves of plants, respectively. Contrast comparisons $(P>F)$ between the necrosis ratings of plots treated with $D$. penicillatum and control plots were 0.029 and 0.940 for Indian Grocery and 0.427 and 0.270 for White Cloud for the lower and upper halves of plants, respectively. 
preparations (28). Spore concentrations three to four times higher than those used in the field experiments presented here $(1.65 \times$ $10^{7} / \mathrm{m}^{2}$ ) may not be unreasonable for field application of a bioherbicide.

The $10 \%$ unrefined corn oil formulations containing fungal conidia caused more disease than the $0.001 \%$ Tween 20 in water formulations in greenhouse experiments. In the field, the $10 \%$ un- refined corn oil formulations containing fungal conidia had a higher initial rate of infection early in the season. The inclusion of unrefined corn oil in bioherbicide formulations has been shown to extend fungal viability prior to the onset of dew and reduce dew period requirements $(4,5)$. Environmental conditions in the field allowed extensive spread of the pathogens between plots, obscuring the effects of formulations.
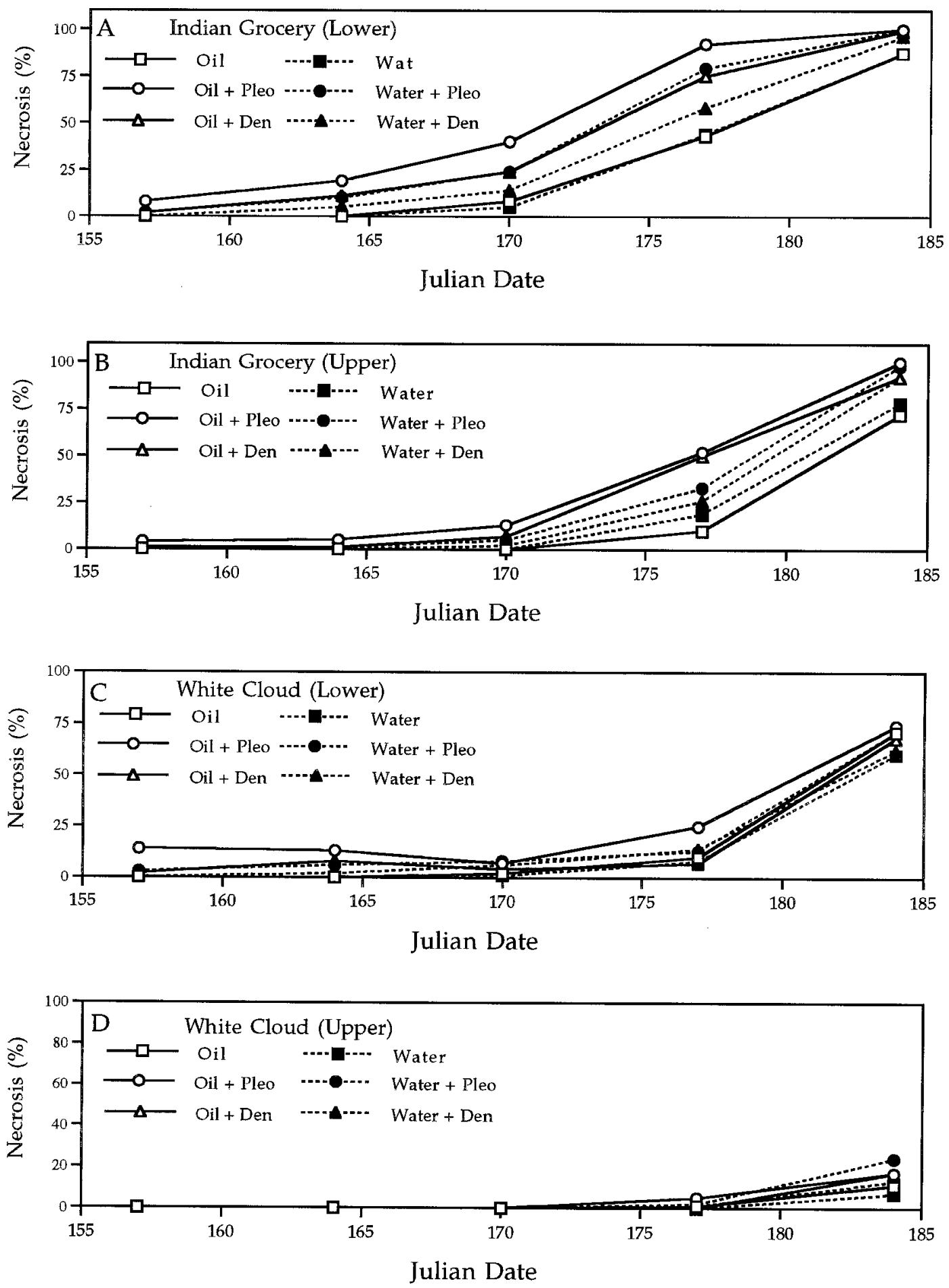

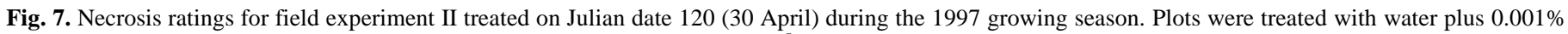

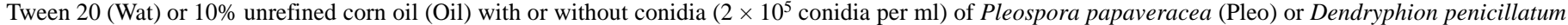

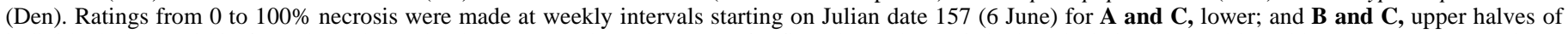

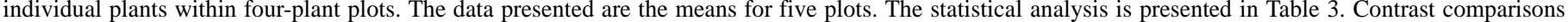

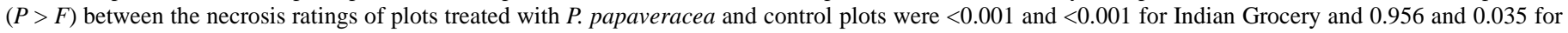

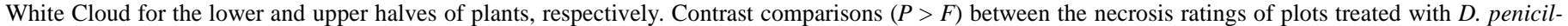

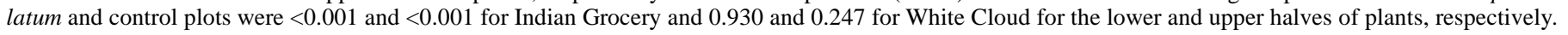


TABLE 4. Number ${ }^{\mathrm{x}}$ of stems with lesions on field-grown opium poppy Indian Grocery after treatment with liquid inoculum of Pleospora papaveracea and Dendryphion penicillatum in 1997

\begin{tabular}{llll}
\hline & \multicolumn{2}{c}{ Formulation } & \\
\cline { 2 - 3 } Isolate & $10 \%$ Corn oil & Water & Mean \\
\hline Field experiment I & & & \\
$P$. papaveracea & 0.8 & 2.4 & $1.6 \mathrm{~A}^{\mathrm{y}}$ \\
D. penicillatum & 0.6 & 1.0 & $0.8 \mathrm{~B}$ \\
Control & 0.2 & 0.2 & $0.2 \mathrm{~B}$ \\
Mean & $0.5 \mathrm{~B}^{\mathrm{z}}$ & $1.2 \mathrm{~A}$ & \\
Field experiment II & & & \\
$P$. papaveracea & 0.8 & 3.4 & $2.1 \mathrm{~A}$ \\
D. penicillatum & 1.0 & 2.0 & $1.5 \mathrm{~A}$ \\
Control & 0.0 & 0.0 & $0.0 \mathrm{~B}$ \\
Mean & $0.6 \mathrm{~B}$ & $1.8 \mathrm{~A}$ & \\
\hline
\end{tabular}

$\mathrm{x}$ The average number of plants per four-plant plots with stem lesions greater than or equal to $2.45 \mathrm{~cm}$ is presented.

y The means within columns for field experiment I or II followed by different letters are significantly different $(P \leq 0.05)$.

${ }^{\mathrm{z}}$ The means within rows followed by different letters are significantly different $(P \leq 0.05)$.

TABLE 5. Effect of treatment with liquid inoculum of Pleospora papaveracea and Dendryphion penicillatum on capsule weight of field-grown opium poppy in 1997

\begin{tabular}{|c|c|c|c|}
\hline \multirow[b]{2}{*}{ Isolate } & \multicolumn{2}{|c|}{ Formulation } & \multirow[b]{2}{*}{ Mean } \\
\hline & $10 \%$ Corn oil & Water & \\
\hline \multicolumn{4}{|l|}{ Field experiment I } \\
\hline \multicolumn{4}{|l|}{ Indian Grocery } \\
\hline P. papaveracea & $8.0^{\mathrm{x}}$ & 6.6 & $7.3 \mathrm{~B}^{\mathrm{y}}$ \\
\hline D. penicillatum & 9.8 & 9.9 & $9.9 \mathrm{~A}$ \\
\hline Control & 10.7 & 9.7 & $10.2 \mathrm{~A}$ \\
\hline Mean & $9.5 \mathrm{~A}^{\mathrm{z}}$ & $8.7 \mathrm{~A}$ & \\
\hline \multicolumn{4}{|l|}{ White Cloud } \\
\hline P. papaveracea & 3.0 & 3.8 & $3.4 \mathrm{~A}$ \\
\hline D. penicillatum & 3.2 & 2.6 & $2.9 \mathrm{~A}$ \\
\hline Control & 3.7 & 2.4 & $3.1 \mathrm{~A}$ \\
\hline Mean & $3.3 \mathrm{~A}$ & $2.9 \mathrm{~A}$ & \\
\hline \multicolumn{4}{|l|}{ Field experiment II } \\
\hline \multicolumn{4}{|l|}{ Indian Grocery } \\
\hline P. papaveracea & 12.6 & 12.6 & $12.6 \mathrm{~B}$ \\
\hline D. penicillatum & 10.9 & 12.9 & $11.9 \mathrm{~B}$ \\
\hline Control & 14.7 & 16.1 & $15.4 \mathrm{~A}$ \\
\hline Mean & $12.7 \mathrm{~A}$ & $13.9 \mathrm{~A}$ & \\
\hline \multicolumn{4}{|l|}{ White Cloud } \\
\hline P. papaveracea & 2.7 & 2.7 & $2.7 \mathrm{~B}$ \\
\hline D. penicillatum & 3.4 & 3.0 & $3.2 \mathrm{AB}$ \\
\hline Control & 3.7 & 3.8 & $3.8 \mathrm{~A}$ \\
\hline Mean & $3.3 \mathrm{~A}$ & $3.2 \mathrm{~A}$ & \\
\hline
\end{tabular}

${ }^{x}$ Capsule weight (gram per plant).

y The means within columns for Indian Grocery or White Cloud within field experiments I and II followed by different letters are significantly different $(P \leq 0.05)$.

${ }^{\mathrm{z}}$ The means within rows followed by different letters are significantly different $(P \leq 0.05)$.

The water-based formulations caused more stem lesions, while the oil-based formulations tended to cause more initial foliar symptoms. The greater viscosity of the unrefined corn oil formulation can reduce required spray volumes $(4,5)$. When applied with volumes equal to the water-based formulations, the unrefined corn oil formulation kept the spores on the leaf surface, causing higher initial foliar infection rates.

Both $P$. papaveracea isolate Pf96 and D. penicillatum isolate Cf96 were pathogenic on opium poppy, causing distinct dark brown lesions on poppy leaves and stems. The symptomology of disease caused by the two fungi was similar, although only $P$. papaveracea infected opium poppy plants after overwintering in poppy stubble. $P$. papaveracea isolate Pf96 was more competitive than was $D$.
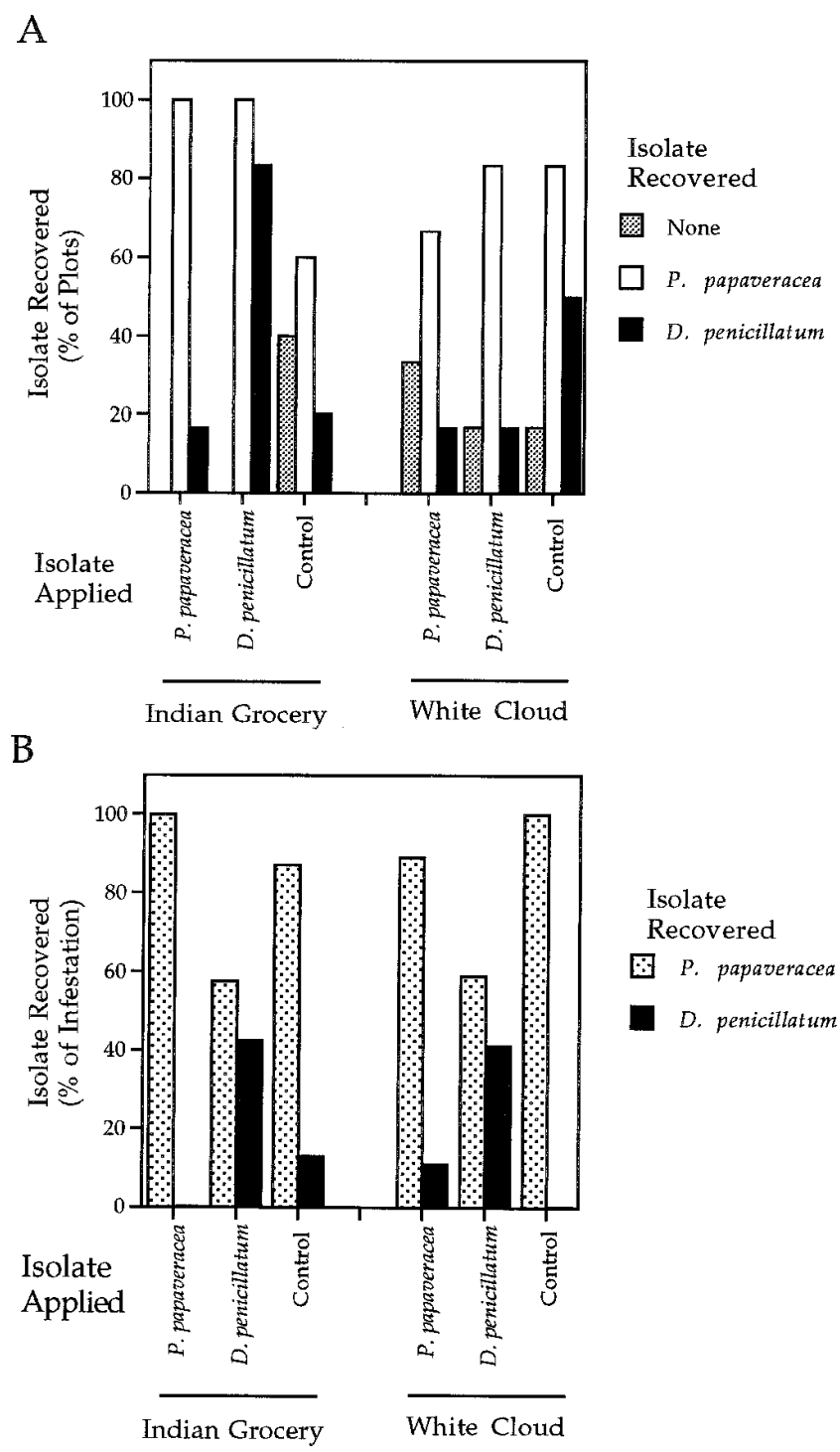

Fig. 8. Frequency of isolation of Pleospora papaveracea and Dendryphion penicillatum from poppy capsules after various treatments were applied in field experiment I in 1997. The data were recorded as A, percentage of plots whose capsules were infested with $P$. papaveracea, $D$. penicillatum, or both; and as $\mathbf{B}$, percentage of total fungal growth from the infested material represented by these fungi. Tissues were sampled from three plots for each treatment combination for each field experiment.

penicillatum isolate Cf96 in the field, greenhouse studies, and detached-leaf studies, which corroborates other observations with these and other isolates carried out in growth chambers (23). Under our field conditions, the rates and formulations of the pathogens were unable to provide inundative bioherbicidal control, resulting in quick kill of opium poppy (6). These results lead us to suggest that increasing the spore concentrations, altering the formulations (5), and applying the formulations to opium poppies at different stages of maturity, either alone or in combination, might allow development of a viable biocontrol strategy for control of opium poppy under field conditions.

\section{ACKNOWLEDGMENTS}

We thank M. Strem, M. Blum, D. Clark, and S. Slater for their dedication to this project, including assistance with experimental setup and data collection. 


\section{LITERATURE CITED}

1. Bailey, B. A., Apel-Birkhold, P. C., Gracia-Garza, J., Hebbar, K. P., Nelson, A. J., Lumsden, R. D., and Elias, K. S. 1997. Strategies for biocontrol of narcotic plants. Pages 25-33 (Section 4) in: Proc. 1997 ONDCP (Off. Natl. Drug Control Policy) Int. Technol. Symp. U.S. Government Printing Office, Washinton, DC.

2. Ballarin, C. 1950 Unterscuhungen uber Helminthosporium papaveris. Phytopathol. Z. 16:399-442.

3. Bogarada, A. P., Lyman, V. E., and Taranich, A. P. 1971 On the resistance of poppy to Helminthosporiosis. Sel. Semenovod. (Mosc.) 36:78-79.

4. Boyette, C. D. 1994. Unrefined corn oil improves the mycoherbicidal activity of Colletotrichum truncatum for hemp Sesbania (Sesbania exaltata) control. Weed Technol. 8:526-529.

5. Boyette, C. D., Quimby, Jr., P. C., Caesar, A. J., Birdsall, J. L., Connick, Jr., W. J., Daigle, D. J., Jackson, M. A., Egley, G. H., and Abbas, H. K. 1996. Adjuvants, formulations, and spraying systems for improvement of mycoherbicides. Weed Technol. 10:637-644.

6. Charudattan, R. 1988. Inundative control of weeds with indigenous fungal pathogens. Pages 86-110 in: Fungi in Biological Control Systems. M. N. Burge, ed. Manchester University Press, Manchester, England.

7. Choudhary, D. K., Kaul, B. L., Kak, S. N., Singh, C., and Ram, G. 1977. Cultivation and utilization of opium poppy in India: A review. Indian Drugs 15:2-8.

8. Czyzewska, S., and Zarzycka, H. 1960. Niektore dane z biologii grzyba Helminthosporium papaveris Hennings, stadium doskonale Pleospora papaveracea (Wint) de Not. Acta Agrobot. 10:41-51.

9. Dean, R. A. 1997. Signal pathways and appressorium morphogenesis. Annu. Rev. Phytopathol. 35:211-234.

10. Ellis, M. B. 1971. Dematiaceous hyphomycetes. Commonwealth Mycological Institute, Kew, Surrey, England.

11. Farr, D. F., O'Neill, N. R., and van Berkum, P. B. 2000. Morphological and molecular studies on Dendryphion penicillatum and Pleospora papaveracea, pathogens of Papaver somniferum. Mycologia 92:145-153.

12. Hebbar, K. P., O'Neill, N. R., Bailey, B. A., and Lumsden, R. D. 1997. Fermentation and formulation of Dendryphion penicillatum, a potential mycoherbicide of Papaver somniferum. (Abstr.) Phytopathology 87(suppl.):S41.

13. Holmstrom-Ruddick, B., and Mortensen, K. 1995. In vitro formation and survival of appressoria of a mycoherbicide agent, Colletotrichum gloeosporioides f.sp. malvae and a benomyl-resistant strain, HP4.5RR. Mycol. Res. 99:1103-1107.

14. Horowitz, M. 1980. Herbicidal treatments for the control of Papaver somniferum L. Bull. Narcotics XXXII 1:33-43.

15. Kaiser, W. J. 1983. Plant introduction and related seed pathology research in the United States. Seed Sci. Technol. 11:1197-1212.

16. Klomparens, K. L., Flegler, S. L., and Hooper, G. R. 1986. Procedures for Transmission and Scanning Electron Microscopy for Biological and Medical Science, A Laboratory Manual, 2nd ed. Ladd Research Indus- tries, Burlington, VT.

17. Krikorian, A. D., and Ledbetter, M. C. 1975. Some observations on the cultivation of opium poppy (Papaver somniferum L.) for its latex. Bot. Rev. 42:30-103.

18. Meffert, M. E. 1950. Ein beirtag zur biologie und morphologie der erreger der parasitaren blattdurre des mohns. Z. Parasitenkd. 14:442-498.

19. Milatovic, I. 1950. Prilog poznavanju gljive Pleospora calvescens (Fr.) Tulasne na maku. Poljopr. Znan. Smotra 13:121-132.

20. The National Drug Control Strategy. 1998. Budget Summary. Barry R. McCaffrey, Director, Office of National Drug Control Policy, Executive Office of the President, Washington, DC. February 1998

21. Nicole, M., Ruel, K., and Ouellette, G. B. 1994. Fine morphology of fungal structures involved in host wall alterations. Pages 13-30 in: Host Wall Alterations by Parasitic Fungi. O. Petrini and G. B. Ouellette, eds. The American Phytopathological Society, St. Paul, MN.

22. O'Neill, N. R., and Jennings, J. C. 1997. Dendryphion penicillatum, a destructive seed-borne pathogen of Papaver somniferum. (Abstr.) Phytopathology 87(suppl.):S73

23. O’Neill, N. R., Jennings, J. C., Bailey, B. A., and Farr, D. F. 2000. Dendryphion penicillatum and Pleospora papaveracea, destructive seedborne pathogens and potential mycoherbicides for Papaver somniferum. Phytopathology 90:691-698.

24. Schmitt, C. G., and Lipscomb, B. 1975. Pathogens of selected members of the Papaveraceae-An annoted bibliography. Agric. Res. Service, U.S. Dep. Agric., Belsville, MD.

25. Sethi, K. L., Sapra, R. L., Gupta, R., Dhindsa, K. S., and Sangwan, N. K. 1990. Performance of poppy cultivars in relation to seed, oil and latex yields under different environments. J. Sci. Food Agric. 52:309-313.

26. Singh, H. G. 1982. Cultivation of opium poppy. Pages 120-138 in: Cultivation and Use of Medicinal Plants. C. K. Atal and B. M. Kapur, eds. Regional Research Laboratory Council of Scientific and Industrial Research, Jammu-Tawi, New Delhi, India.

27. Sivanesan, A., and Holliday, P. 1982. Pleospora papaveracea. CMI Descr. Pathog. Fungi Bact. 730:1-2.

28. Templeton, G. E., and Heiny, D. K. 1989. Improvement of fungi to enhance mycoherbicide potential. Pages 127-152 in: Biotechnology of Fungi for Improving Plant Growth. J. M. Whipps and R. D. Lumsden, eds. Cambridge University Press, Cambridge, England.

29. Watson, A. K., and Wymore, L. A. 1990. Identifying limiting factors in the biocontrol of weeds. Pages 305-316 in: New Directions in Biological Control: Alternatives for Suppressing Agricultural Pests and Disease. R. R. Baker and P. E. Dunn, eds. Alan R. Liss, Inc., New York.

30. Yang, X. B., and TeBeest, D. O. 1993. Epidemiological mechanisms of mycoherbicide effectiveness. Phytopathology 83:891-893.

31. Zhukovskii, P. M., and Bazilevskaya, N. A. 1933. Opium poppy. Pages 476-507 in: La Turquie Agricole-Krashkaw. Moscow. (Pages 1-40 in: Technical translation from Russian. TT 74-52024, 1975, Armerind Publishing Co. Pvt. Ltd., New Delhi, India.) 